6. Лавринович Л. Сучасний український постмодернізм напрям?стиль? метод? Слово $і$ час. 2001. № 1. С. 39-46.

7. Печерських Л. Концептуальні дискурси сміхової культури в українській прозі 90-х років ХХ століття (творчість Юрія Андруховича): Монографія. Харків: Майдан, 2008. 160 с.

8. Поліщук О. Автор і персонаж в українській новітній прозі. К.: ПЦ «Фоліант», 2008. 176 с.

DOI https://doi.org/10.30525/978-9934-26-073-5-1-28

\title{
АВТОРСЬКИЙ ТЕКСТ-МІФ ТА МОТИВ «ПОДОРОЖІ У ЧАСІ» ЯК СПОСІБ РЕЦЕПЦІЇ ТРАДИЦІЙНОГО СЮЖЕТНО-ОБРАЗНОГО МАТЕРІАЛУ НА ПРИКЛАДІ ДРАМИ ЛЕСІ ВОЛОШИНОЇ «ЕЛЬЗА. ПРИТЧА ПРО ЛЮБОВ»
}

\author{
Гуцол М. І. \\ кандидат філологічних наук, доцент, \\ дочент кафедри мовознавства \\ Івано-Франківського національного медичного університету \\ м. Івано-Франківськ, Україна
}

Кожна історична епоха відображається через міфологізацію власного минулого та запозичення міфологічних сюжетів та образів з інших культур. Міфологія здавна приваблювала дослідників, а сучасна література, означена як епоха «ендизмім» (за визначенням Джона Барта) презентує цілісну систему апелювання до першоджерел людської цивілізації в пошуках відповіді на «вічні питання» буття. Водночас «альтернативна реальність» міфу відкриває неозорий простір для письменницьких експериментів і творчих рефлексій.

У вітчизняному літературознавстві крізь призму міфокритики розглядали широкий спектр проблем у своїх дослідженнях Дж. Грабович, Олена Бондарєва, Оксана Забужко, Ніла Зборовська, Оксана Когут та інші. Науковці використовують напрацювання як антропологічної гілки (Фрейзер), так і архетипної критики та психоаналітики (Сергій Аверинцев, Мірча Еліаде, Нортроп Фрай), постструктуралістів, семіотиків і деконструктивістів (Ролан Барт, Жак Деррида, Мішель Фуко). Проте сьогодні, на жаль, ще немає досліджень інтерпретації традиційної сюжетно-образної системи міфу в контексті української постмодерної драматургії. 
Предметом дослідження стала драма Лесі Волошиної «Ельза. Притча про любов», яка є однією з циклу «Ще одна притча про любов», до якого входять п’єси з аналогічними заголовками, що відрізняються історіями головних героїнь та ідентифікують їхні назви відповідно до імен (Моноле, Марта, Ельза). У такий спосіб драматург уводить античну традицію вшанування імені, що єдино значуще, сповнене сенсу та гідне мати власну історію, адже хто не має імені, той і не існує - це велике ніщо, порожнеча чи анонім. Тож варто лише назвати імена Одіссея, Паріса, Гелени, Посейдона чи будь-кого із сонму античних богів та героїв, як одразу постають асоціації з відповідними міфологічними сюжетами.

В основу сюжету драми Лесі Волошиної «Ельза. Притча про любов» покладено чарівне перетворення морської царівни у звичайну жінку через втрату (знищення / викрадення) предмета перевтілення. У сучасному тексті-міфі цю функцію виконує тюленяча шкірка, яку забрав ще п'ятнадцять років тому юний рибалка-красень - Родерік, поки Ельза, скинувши іï, безпечно купалася в морі. Цей мотив $є$ типовим і часто вживаним в усній народній творчості, як-от в українській народній казці «Кривенька Качечка» (викинуте пір'ячко) чи в російському фольклорі історії про Царівну-жабу (спалена шкірка). Проте в п’єсі сучасного автора сюжет ускладнено свідомим вибором героїні, адже насправді Ельза добре знає, де знаходиться ця шкірка і будь-коли може залишити чоловіка та дітей і повернутися в морське царство.

Цікавою є також типологічна схожість образу Ельзи та Ізіди-Селени в романі Апулея «Метаморфози, або Золотий осел». Героїня з'явилася у сні Луцію-віслюку в цій дуалістичній подобі: «...бачу, як з морських хвиль винурюється повний, напрочуд лискучий місяць. Довкіл панувала таємнича глуха ніч, і я перейнявся вірою, що велична богиня місяця наділена особливою владою, що всі людські справи залежать від ії волі (...). От і вирішив я звернутися 3 покірною молитвою до богині в тій іпостасі, в якій вона мені з'явилася» [1, с. 165]. Дослідники також вказують на інтертекстуальний зв'язок тексту-міфу про Ельзу з архетипами сюжетів про Ромео і Джульєту (Вільяма Шекспіра), Русалонькою (Ганса Христиана Андерсена), Мавкою (Лесі Українки) [3; 91]. Ми б доповнили цей перелік також мотивом незнання героями свого справжнього (королівського) походження, притаманний багатьом світовим міфологіям.

У сучасній п'єсі героїня свідомо відмовляється від ролі царівни морських глибин і приймає ті випробування, що випадають на долю людини. Драматург космогонізує часопростір Ельзи, актуалізуючи 
сюжет світоустрою в античних міфах, де в ієрархії головних богів окремішне місце посідає володар водяних просторів. Почуття до смертного витіснили всі інші життєві овиди морської царівни. Образ Родеріка постає суголосно до вимог античного ідеалу краси: цілковитої гармонії тіла (гарний юнак з міцною статурою) i духу (відважний i романтичний, здатний збудити почуття не лише земної дівчини, але й володарки морських глибин). У цьому юнакові відтепер зосередився ввесь усесвіт Ельзи.

У поетиці п'єси Лесі Волошиної ключове місце посідає код любові, на що вказує сучасна дослідниця Оксана Когут: «батьківської, братньої, подружньої, синівської, дошукування іiі правдивості, як сенсожиттєвої істини. Адже не суттєво хто кого здобував у коханні, головно, чи є воно цінністю для них» [4, с. 138]. Проте, на нашу думку, варто звернути особливу увагу на власне християнський наратив - любов до ближнього та сенс добровільної офіри власного життя Сина Божого задля спасіння людей. Семантично смерть є антитезою любові як вищого прояву життя. Відтак, любов - єдина сила, здатна здолати смерть у християнському дискурсі. Драматург залишає відкритим для дискусії питання про життя без любові (без коханого чоловіка / дружини), апелюючи до угоди про безсмертя в обмін на кохання. Таке існування гірше за смерть, людські почуття не досяжні богам (у сюжеті лише опосередковано присутній міфологічний образ Посейдона), адже імені батька Ельзи письменниця так і не називає.

Упродовж подружнього життя Родерік та Ельза щоденно клопочуться, щоб бодай якось вижити. На нашу думку, драматург, актуалізуючи основи християнського світогляду, тісно сплітає їх у канві сюжету з античною міфологічною космогонією. Актуалізація відбувається через виведення засадничого концепту - любові-життя - як сили всепереможної, головної в християнській космогонії. Із розгортанням подій у п'єсі поступово зміщується іiі семантичне значення, аж поки не набуває рис антитези - ненависті-смерті, що руйнує та нищить. Зміна полюсів добра та зла в контексті любові спричинює катастрофу в космогонії жінки. Зокрема це стосується не так подружньої любові, як стосунків між Ельзою та батьком. Ця любов панівна, котра не терпить жодних інших думок, деспотична i руйнівна, проте намагається виправдатись Братовою тезою.

У фіналі п’єси відбувається кардинальна зміна зовнішнього вигляду Ельзи (вона знову молода, гарна і заможна) драматург детермінує також зміни на рівні поведінки та мови, проте не так, як зазвичай очікує читач / глядач. У фіналі перед нами - пригнічена та зацькована жінка, котра 
лякається власного голосу і не сміє навіть пригадувати чи думати про минулі п'ятнадцять років на землі. Жінка вдає веселощі та радість від осягнення статусу царівни. У ремарках драматург акцентує на одязі Ельзи, рукави якого схожі на крила, та в описі місця іiі перебування, де вона схожа радше на птаха в золотій клітці. Маємо алогічне поєднання онірії першостихій: води та повітря, проте обидві символізують свободу, недосяжну людині, що є дитям землі.

Нам імпонують висновки, які робить Олена Бондарєва, аналізуючи драми Лесі Волошиної. Науковець акцентує на «полісемантичності сюжетів і образів; можливості традиціоналізації; апеляції до традиційних сюжетів, образів і мотивів світової літератури, їхнє ремінісцентне відтворення; двоплановість у викладі матеріалу і поява на цьому грунті потужного підтексту» [2, с. 348]. Отже, інтерпретуючи традиційні сюжети та образи міфу про морську царівну драматург презентує власні інтенції їхнього розуміння-осягнення, надаючи драмі форми притч. На думку Галини Драненко, «міф $є$ живим джерелом, невичерпним ресурсом сюжетів та мотивів, але в багатьох випадках «рекреація» не зводиться до простого запозичення міфологічної оповіді, вона, навпаки, забезпечує їй діалектичну трансформацію, яка містить також процеси деміфізації. Якщо міфологія представляє оновлений об'єктивізований стан певного типу історій, то міф сам по собі означає семантичну матрицю, символічне ядро, яке дозволяе створити оповіді навколо визначеної структури» [3, с. 107]. Леся Волошина органічно поєднує в авторському тексті-міфі світоглядні парадигми античності та християнства, демонструючи численні алюзії та ремінісценції, інтегруючи античний текст в канву драми через інтертексти, міфологічні асоціації, прямі та опосередковані.

\section{Література:}

1. Кобів Й., Цимбалюк Ю. (пер. із лат.) Апулей. Метаморфози, або Золотий осел. Фоліо. Харків, 2004. 239 с.

2. Бондарєва О.С. Міф і драма у новітньому літературному контексті: поновлення структурного зв'язку через жанрове моделювання: монографія / за ред. О. Є. Бондарєвої. Київ: Четверта хвиля, 2006. 512 с.

3. Бондарєва О. С. Драматизм міфу і міфологізм драми: монографія / за ред. О. Є. Бондарєвої. Херсон: Персей, 2000. 188 с.

4. Драненко Г. Ф. Міф як форма сенсу та сенс форми. Міфокритичне прочитання творів Б.-М. Кольтеса: монографія / за ред. Г. Ф. Драненко. Чернівці: Чернів. нац. ун-т, 2011. 440 с. 
5. Волошина Л. Ельза: притча про любов. Украӥнський письменник. 2006. Вип. 3. С. 73-88.

6. Когут О.В. Архетипні сюжети та образи в сучасній українській драматургії: монографія/ за ред. О.В. Когут. Рівне: НВУГП, 2010. 440 с.

DOI https://doi.org/10.30525/978-9934-26-073-5-1-29

\title{
РОМАН «УТОПЛЕННЯ» ОЕ КЕНДЗАБУРО: МІСЦЕ МИТЦЯ/МИСТКИНІ В ІНТЕРПРЕТАЦЇ̈ КОНЦЕПЦІЇ «ДУХУ ЕПОХИ» НАЦУМО СОСЕКІ
}

\author{
Дудар Я. О. \\ аспірантка кафедри порівняльної філології східних \\ та англомовних країн \\ Дніпровського начіонального університету імені Олеся Гончара \\ м. Дніпро, Украӥна
}

Однією з характерних стильових рис всієї творчості Ое Кендзабуро $є$ саме семантика наративу покоління. В полі зображення постають як сучасники самого письменника, так і молоді, прийдешні покоління - це тло конфлікту людини і їі часу, що простягається майже на століття i визначає мету художнього зображення японського письменника.

Прийняття та пізнання концепції пізнього стилю Едварда В. Саїда [1] визначило та змінило попередньо встановлені письменником канони власного романного стилю, спонукало до перегляду, вигарто-вування еклектичних естетичних категорій в романі «Утоплення» (『水死』, 2009). В цьому тексті автор/наратор майже повністю трансформується у спостерігача, що фіксує у тексті конфлікт нового покоління та свого власного. Проблема постає не просто у зображенні прагнення жінок до визнання своїх здібностей та сили чоловіками, але вже процес, що відбувається. У тексті відсутні знаки питання чи можуть жінки бути «митцем», тут вони знаходять свою унікальність, тому що вони «мисткині» зі своїми власними і новими творчими підходами. Це вже не просто гендерна проблема сприйняття суспільством інваріанту існування жінки-митця, що не має сталого образу у японській культурі, що має власну та нову мову, інструменти та теми; але й проблема боротьби 3 епохою Сьова, що закарбувала образ чоловіка-митця і його власні художні теми. Роман торкається різниці між історичними періодами 